\title{
Arsenic bioavailability to rice plant in paddy soil: influence of microbial sulfate reduction
}

\author{
Yan Jia ${ }^{1,2} \cdot$ Peng Bao ${ }^{2} \cdot$ Yong-Guan $\mathrm{Zhu}^{2,3}$
}

Received: 29 November 2014 / Accepted: 2 April 2015 / Published online: 22 April 2015

(C) Springer-Verlag Berlin Heidelberg 2015

\begin{abstract}
Purpose High arsenic (As) mobility in anaerobic paddy soil due to microbial $\mathrm{Fe}$ - and As-reducing processes results in As accumulation into rice plants. Sulfur (S) also undergoes microbial reducing processes in the anaerobic paddy soil, while this process interacts with the $\mathrm{Fe}$ - and As-reducing processes, forms secondary minerals, and thus influences As mobility in paddy soil. This work was carried out to investigate the role of sulfur and sulfate-reducing bacteria (SRB) in As redox transformation and bioavailability to rice plant in an anaerobic paddy soil.

Materials and methods Anaerobic incubation experiments with or without sulfate $\left(\mathrm{SO}_{4}{ }^{2-}\right)$ and $\mathrm{SRB}$ were carried out to monitor $\mathrm{S}$ and iron $(\mathrm{Fe})$ dynamics and their relations to As speciation and release to soil solution. Rice cultivation in pot experiment was then carried out to check the $\mathrm{SO}_{4}{ }^{2-}$ amendment in bioavailability and uptake into rice plants.

Results and discussion The inoculation of an enriched SRB community into the sterilized paddy soil increased reduction and release of As to the soil solution after flooding, showing its ability in arsenate $(\mathrm{As}(\mathrm{V}))$ as well as $\mathrm{SO}_{4}{ }^{2-}$ reduction to
\end{abstract}

Responsible editor: Yong Sik Ok

Yong-Guan Zhu

ygzhu@rcees.ac.cn

1 National Engineering Laboratory for Hydrometallurgical Cleaner Production Technology, Institute of Process Engineering, Chinese Academy of Sciences, Beijing 100190, China

2 State Key Laboratory of Urban and Regional Ecology, Research Center for Eco-Environmental Sciences, Chinese Academy of Sciences, Beijing 100085, China

3 Key Laboratory of Urban Environment and Health, Institute of Urban Environment, Chinese Academy of Sciences, Xiamen 361021, China arsenite $(\mathrm{As}(\mathrm{III}))$ and sulfide $\left(\mathrm{S}^{2-}\right)$, respectively. Sulfate addition $(2$ and $100 \mathrm{mM})$ into the anaerobic paddy soil increased the reduction of $\mathrm{SO}_{4}{ }^{2-}$ and ferric iron $\left(\mathrm{Fe}^{3+}\right)$ and resulted to lower dissolved As in the soil solution, which limited As mobility in the paddy soil. Application of $\mathrm{SO}_{4}{ }^{2-}\left(100 \mathrm{mg} \mathrm{kg}^{-1}\right)$ into paddy soil finally decreased the concentration of dissolved As in the soil solution by $23.5 \%$ and also decreased As content in rice roots and iron plaque by 22.6 and $30.5 \%$, respectively.

Conclusions The results revealed the important role of sulfur and the SRB activity in As speciation and mobility in anaerobic paddy soil, implying a lower As bioavailability to rice plants under sulfur-enriched anaerobic paddy soil, and an efficient way to reduce As accumulation in rice plants by sulfur fertilization in paddy soils.

Keywords Arsenic · Oryza sativa L. (rice) · Paddy soil · Sulfur $\cdot$ Sulfate-reducing bacteria

\section{Introduction}

Arsenic is a ubiquitous environmental contaminant and a notorious carcinogen posing both acute and chronic adverse effects on human health mainly through ingestion of contaminated water and rice (Zhu et al. 2008a; Rahman et al. 2009; Li et al. 2011). Large areas of farmland have been contaminated by arsenic (As) due to the irrigation with As-enriched groundwater or the contamination by mining and other activities (Zhu et al. 2008b; Smith et al. 2000; Li et al. 2011). In paddy soils, As is released into soil solution mainly in the form of arsenite (As(III)), by As-reducing bacteria and by the reductive dissolution of iron oxyhydroxides which reduces the binding sites of As on minerals (Stroud et al. 2011; Xu et al. 2008). Elevated concentration of As(III) in the soil solution under anaerobic 
condition provides As sources to rice plants (Roberts et al. 2010; Jia et al. 2014). Also, rice absorbs As(III) more efficiently than other cereal crops because of its strong silicon uptake pathway which also allows the quick uptake of As(III) (Ma et al. 2008; Su et al. 2010). Thus, rice is the major As exposure route for people living in Southeast Asia where the paddy soil is As contaminated and rice is the major food source (Mondal and Polya 2008; Zhu et al. 2008a; Li et al. 2011).

It is likely that As shares similar microbial redox transformations with sulfur (S) (Fisher et al. 2008). The reduction of arsenate $(\mathrm{As}(\mathrm{V}))$ to $\mathrm{As}(\mathrm{III})$ and reductive dissolution of iron oxyhydroxides facilitate As release from soil iron oxyhydroxides to the soil solution (Poulton et al. 2004; Hoeft et al. 2004). Microbially mediated reduction of sulfate $\left(\mathrm{SO}_{4}{ }^{2-}\right)$ in the anaerobic soil interacted with changes in speciation and mobility of $\mathrm{Fe}$ and As (Wilkin et al. 2003). Bacterial $\mathrm{SO}_{4}{ }^{2-}$ reduction to sulfide $\left(\mathrm{S}^{2-}\right)$ can immobilize As by facilitating the precipitation of As sulfide and Fe sulfide minerals. The reported iron and arsenic sulfide secondary minerals included mackinawite, siderite, orpiment, and thioarsenites (Kirk et al. 2004; Fisher et al. 2008; Burton et al. 2013, 2014). It is reported that microbial $\mathrm{SO}_{4}{ }^{2-}$ reduction leads to lower concentrations of porewater $\mathrm{Fe}(\mathrm{II})$ and As in a flooded soil, as a result of mackinawite formation and As co-precipitation (Burton et al. 2014). Furthermore, As(III)-mackinawite interactions led to the formation of an orpiment $\left(\mathrm{As}_{2} \mathrm{~S}_{3}\right)$-like species during reduction of $\mathrm{As}(\mathrm{V})$-co-precipitated schwertmannite (Burton et al. 2013, 2014). The extent and strength of As sorption to Fe sulfides depend on aqueous As speciation (Bostick and Fendorf 2003; Jönsson and Sherman 2008; Couture et al. 2013) and iron sulfide mineralogy (Gallegos et al. 2007; Jönsson and Sherman 2008; Renock et al. 2009; Couture et al. 2013). Ultimately, the interactions of these redox transformations determine how sulfate reduction affects As mobility, considering the various sequestration and mobilization processes. Microbial sulfate reduction is thus expected to also play a significant role in determining As transformation and mobility in the paddy soils, but limited researches have done related to sulfate reduction and As mobility in the paddy soil considering As uptake into rice plants.

The reduction of $\mathrm{As}, \mathrm{Fe}$, and $\mathrm{S}$ coexists in the Ascontaminated anaerobic paddy soil and is influenced by different microbial and physico-chemical factors. These processes interact with each other and together determine the transformation and mobility of As in the soil. In this study, incubation experiments and pot experiment were therefore conducted to elucidate the potential coupling of these redox processes in the paddy soil. The role of sulfur and sulfate-reducing bacteria (SRB) on As transformation and mobility in the paddy soil was investigated to elucidate As transformation in paddy soil and its bioavailability to rice plants.

\section{Materials and methods}

\subsection{Anaerobic incubation of paddy soil with $\mathrm{SO}_{4}{ }^{2-}$ addition}

The soil was collected from the plow layer of a paddy field near a mine from Chenzhou, Hunan province of China, with the As concentration of $69.6 \mathrm{mg} \mathrm{kg}^{-1}$. The soil contained $2.98 \mathrm{~g} \mathrm{~kg}^{-1}$ total $\mathrm{N}, 0.67 \mathrm{~g} \mathrm{~kg}^{-1}$ total $\mathrm{P}, 8.8 \mathrm{~g} \mathrm{~kg}^{-1}$ total $\mathrm{K}$, $30.8 \mathrm{~g} \mathrm{~kg}^{-1}$ total $\mathrm{Fe}$, and $0.32 \mathrm{~g} \mathrm{~kg}^{-1}$ total $\mathrm{S}$, and had a $\mathrm{pH}$ value of 6.77. One-hundred grams of dry soil was weighted into serum bottles, added with $100 \mathrm{~mL}$ sterilized water, and then sealed with butyl rubber stoppers and aluminum caps. Three treatments were set: without $\mathrm{SO}_{4}{ }^{2-}$ addition $(0 \mathrm{mM})$; addition of $2 \mathrm{mM} \mathrm{kg}^{-1} \mathrm{SO}_{4}{ }^{2-}\left(\mathrm{Na}_{2} \mathrm{SO}_{4}\right)$ to the soil $(2 \mathrm{mM})$; and addition of $100 \mathrm{mM} \mathrm{kg}^{-1} \mathrm{SO}_{4}{ }^{2-}$ to the soil $(100 \mathrm{mM})$, each with four replicates. The bottles were then incubated in an anaerobic cabinet (Concept 400, Ruskin, UK) at a temperature of $37^{\circ} \mathrm{C}$. Soil solution was extracted with sterile serum during the incubation time of 90 days and passed through a $0.2-\mu \mathrm{m}$ membrane. Concentrations of $\mathrm{S}^{2-}$ and $\mathrm{Fe}^{2+}$ were measured immediately after sampling. Soil solution was then stored at $-20^{\circ} \mathrm{C}$ for further determination of total As concentration and As speciation.

\subsection{Anaerobic incubation of paddy soil with SRB}

An anoxic medium was used for enrichment of SRB from the fresh paddy soil. The medium contained $\left(\mathrm{g} \mathrm{L}^{-1}\right) \mathrm{K}_{2} \mathrm{HPO}_{4} 0.2$, $\mathrm{MgSO}_{4} \cdot 7 \mathrm{H}_{2} \mathrm{O} 0.2,\left(\mathrm{NH}_{4}\right)_{2} \mathrm{Fe}\left(\mathrm{SO}_{4}\right)_{2} \cdot 6 \mathrm{H}_{2} \mathrm{O} \quad 0.2, \mathrm{Na}_{2} \mathrm{SO}_{4} 4.0$, $\mathrm{CaCl}_{2} \cdot 2 \mathrm{H}_{2} \mathrm{O} 0.5$, yeast extract 1.0 , vitamin $\mathrm{C} 0.2$, sodium thioglycolate 0.1 , and sodium lactate 3.5 . The $\mathrm{pH}$ of the medium was adjusted to 7.2 with $\mathrm{NaOH}$ solution. The medium was autoclaved and cooled to room temperature under an atmosphere of $\mathrm{N}_{2} / \mathrm{CO}_{2}(90 / 10, v / v)$. Fresh paddy soil samples $(5.0 \mathrm{~g})$ were weighted into $100 \mathrm{~mL}$ anoxic water and mixed homogeneously, and then $5 \mathrm{~mL}$ of suspension was added to the serum bottle containing $50 \mathrm{~mL}$ medium and then incubated at $30{ }^{\circ} \mathrm{C}$ in the dark. New cultures were inoculated with $10 \%$ in a column $(v / v)$, and a culture with a stable SRB community was obtained after 15 transfers (Bao et al. 2012).

One-hundred grams of paddy soil was filled to the serum bottles, added with $100 \mathrm{~mL}$ sterilized water, and then sealed with a butyl rubber stopper and an aluminum cap. The bottles with paddy soil were then sterilized at $121^{\circ} \mathrm{C}$ for $30 \mathrm{~min}$. Four treatments were set: without $\mathrm{SO}_{4}{ }^{2-}$ addition and without $\mathrm{SRB}$ addition (-S-SRB); without $\mathrm{SO}_{4}{ }^{2-}$ addition and with $\mathrm{SRB}$ addition $(-\mathrm{S}+\mathrm{SRB})$; with $\mathrm{SO}_{4}{ }^{2-}$ addition and without $\mathrm{SRB}$ addition (+S-SRB); and with $\mathrm{SO}_{4}{ }^{2-}$ addition and with $\mathrm{SRB}$ addition $(+\mathrm{S}+\mathrm{SRB})$, each with four replicates. Sulfate addition into the bottle was $20 \mathrm{mM} \mathrm{kg}^{-1}$ in the treatments with $\mathrm{SO}_{4}{ }^{2-}$, and the incubation of SRB from the enrichment solution was $2 \mathrm{~mL}$ in volume. Treatments without SRB were 
added with $2 \mathrm{~mL}$ sterilized enrichment solutions. The soil solution was extracted with a sterile syringe during the incubation time and passed through a $0.2-\mu \mathrm{m}$ membrane (Millipore, USA). The concentrations of $\mathrm{S}^{2-}, \mathrm{Fe}^{2+}$, and As; soil $\mathrm{pH}$; and Eh were then determined.

\subsection{Rice cultivation}

Phosphorus as $\mathrm{CaHPO}_{4} \cdot 2 \mathrm{H}_{2} \mathrm{O}$ at $0.15 \mathrm{~g} \mathrm{P}_{2} \mathrm{O}_{5} \mathrm{~kg}^{-1}$, potassium as $\mathrm{KCl}$ at $0.2 \mathrm{~g} \mathrm{~K}_{2} \mathrm{O} \mathrm{kg}$, and nitrogen as $\mathrm{CO}\left(\mathrm{NH}_{2}\right)_{2}$ at $0.2 \mathrm{~g} \mathrm{~N} \mathrm{~kg}^{-1}$ (as solutions) were added to the air-dried soil. The soil was mixed with $\mathrm{SO}_{4}{ }^{2-}$ at two levels: 0 and $100 \mathrm{mg} \mathrm{kg}^{-1}$, mixed throughout and transferred into PVC pots (each of $1 \mathrm{~kg}$ soil).

Seeds of rice (Oryza sativa) were soaked in $1 \% \mathrm{NaClO}$ for $15 \mathrm{~min}$, washed several times with double-distilled water, and germinated in perlite. The healthy and uniform-sized seedlings were selected and randomly transplanted to PVC pots, with one plant in each pot. The four treatments were as follows: $-\mathrm{S}-\mathrm{R}$ (without sulfur addition and without rice plant), + $\mathrm{S}-\mathrm{R}$ (with sulfur addition and without rice plant), $-\mathrm{S}+\mathrm{R}$ (without sulfur addition and with rice plant), and $+\mathrm{S}+\mathrm{R}$ (with sulfur addition and with rice plant), each of four replicates. A soil solution sampler (Rhizon Soil Moisture Samplers, Rhizosphere Research Products, The Netherlands) was placed in the center of each pot, and the soil solution was timely sampled, passed through a $0.45-\mu \mathrm{m}$ filter, and maintained in a $\mathrm{HNO}_{3}$ concentration of $1 \%$ for further determination of $\mathrm{Fe}^{2+}$, As speciation, and total As concentration. Redox potential (Eh) in the soil was measured timely using Pt electrodes with $\mathrm{Ag} / \mathrm{AgCl}$ as the reference electrode. After growth for 110 days, rice plants were harvest for determination of dry biomass and As content.

\subsection{Determination of $\mathrm{Fe}^{2+}, \mathrm{S}^{2-}$, and As concentrations}

Concentrations of $\mathrm{Fe}^{2+}$ in the soil solution were determined by a spectrophotometer according to the reported method (Huang et al. 2012). Concentrations of $S^{2-}$ were measured using the spectrophotometer method immediately after sampling of the soil solution (Cord-Ruwisch 1985). Arsenic speciation in the soil solution was determined by high-performance liquid chromatography-inductively coupled plasma mass spectrometry (HPLC-ICP-MS) (Agilent 1200 and Agilent 7500, Agilent Technologies, USA), and total As concentration was determined by ICP-MS (Agilent 7500, Agilent Technologies, USA). Arsenic speciation was separated by a PRP-X100 anion exchange HPLC column $(150 \times 4.1 \mathrm{~mm}$, Hamilton, Netherlands) under the solution of $7.0 \mathrm{mmol} \mathrm{L}^{-1}\left(\mathrm{NH}_{4}\right)_{2} \mathrm{HPO}_{4}$ and $7.0 \mathrm{mmol} \mathrm{L}^{-1} \mathrm{NH}_{4} \mathrm{NO}_{3}(\mathrm{pH}=6.2)$. Roots were incubated in DCB (dithionite-citrate-bicarbonate) solution for the extraction of iron plaques on the root surface (Taylor and Crowder 1983; Liu et al. 2004). Arsenic concentration in the iron plaque extraction solution was determined by ICP-MS (Agilent 7500, Agilent Technologies, USA). After DCB extraction, roots and shoots were frozen dried, grinded to powder, and stored at $-80{ }^{\circ} \mathrm{C}$ in a refrigerator. The total As concentration in shoots and DCB extracted roots was digested in $\mathrm{HNO}_{3}$ using a microwave digestion system (MARS, CEM Microwave Technology Ltd., USA) and determined using ICP-MS (Sun et al. 2008).

\section{Results}

\subsection{Dynamics of $\mathrm{S}^{2-}, \mathrm{Fe}^{2+}$, and $\mathrm{As}$ under the addition} of $\mathrm{SO}_{4}{ }^{2-}$

Addition of $\mathrm{SO}_{4}{ }^{2-}$ into the paddy soil altered the dynamics of $\mathrm{S}, \mathrm{Fe}$, and As in serum incubation experiment 1 (Fig. 1). Sulfide concentrations increased in the first 40 days and then decreased later during the incubation in all treatments (Fig. 1a). Addition of $\mathrm{SO}_{4}{ }^{2-}$ (2 and $100 \mathrm{mM}$ ) into the paddy soil significantly increased $\mathrm{S}^{2-}$ concentration in the soil solution compared with the control treatment, especially in the treatment with $100 \mathrm{mM} \mathrm{SO}_{4}{ }^{2-}$. In day 40 , the $\mathrm{S}^{2-}$ concentration in the $100 \mathrm{mM} \mathrm{SO}_{4}{ }^{2-}$ treatment was seven times higher than that without $\mathrm{SO}_{4}{ }^{2-}$ addition. Ferrous iron concentration was significantly increased during the incubation, in all the three treatments, and was much higher (about $30 \%$ higher) in the treatment with higher $\mathrm{SO}_{4}{ }^{2-}(100 \mathrm{mM})$ addition (Fig. 1b). The concentrations of dissolved As in soil solution were increased in the first 40 days, and then retained in a steady level in the treatments by 2 and $100 \mathrm{mM} \mathrm{SO}_{4}{ }^{2-}$ amendment, but still kept increasing in the non-sulfate addition control treatment (Fig. 1c). Addition of $\mathrm{SO}_{4}{ }^{2-}$ into the soil resulted in a lower As concentration in the soil solution after incubation for 40 days. Arsenic concentration at day 90 in the treatment without $\mathrm{SO}_{4}{ }^{2-}$ amendment was about $90 \%$ higher than that with $100 \mathrm{mM} \mathrm{SO}_{4}{ }^{2-}$ amendment. The ratio of $\mathrm{As}(\mathrm{III}) / \mathrm{As}(\mathrm{V})$ increased steadily during the incubation and was higher with $\mathrm{SO}_{4}{ }^{2-}$ addition (Fig. 1d).

\subsection{Dynamics of $\mathrm{S}^{2-}, \mathrm{Fe}^{2+}$, and As under the addition of SRB}

Concentrations of $\mathrm{S}^{2-}, \mathrm{Fe}^{2+}$, and $\mathrm{As}$ and ratio of $\mathrm{As}(\mathrm{III}) / \mathrm{As}(\mathrm{V})$ in the soil solution were not changed during the experiment in sterilized soil without bacteria addition, regardless of the $\mathrm{SO}_{4}{ }^{2}$ - addition, in serum incubation experiment 2 (Fig. 2). In contrast, SRB inoculation into the paddy soil significantly increased the concentrations of $\mathrm{S}^{2-}$ and $\mathrm{Fe}^{2+}$ in the soil solution (Fig. 2a, c). $\mathrm{S}^{2-}$ concentration was greatly elevated at day 10 and day 20 for $+\mathrm{S}+\mathrm{SRB}$ and $-\mathrm{S}+\mathrm{SRB}$, respectively. $\mathrm{Fe}^{2+}$ concentration was in average $45.3 \%$ higher during the experiment in the treatment with both $\mathrm{SO}_{4}{ }^{2-}$ and $\mathrm{SRB}$ addition $(+\mathrm{S}+$ 

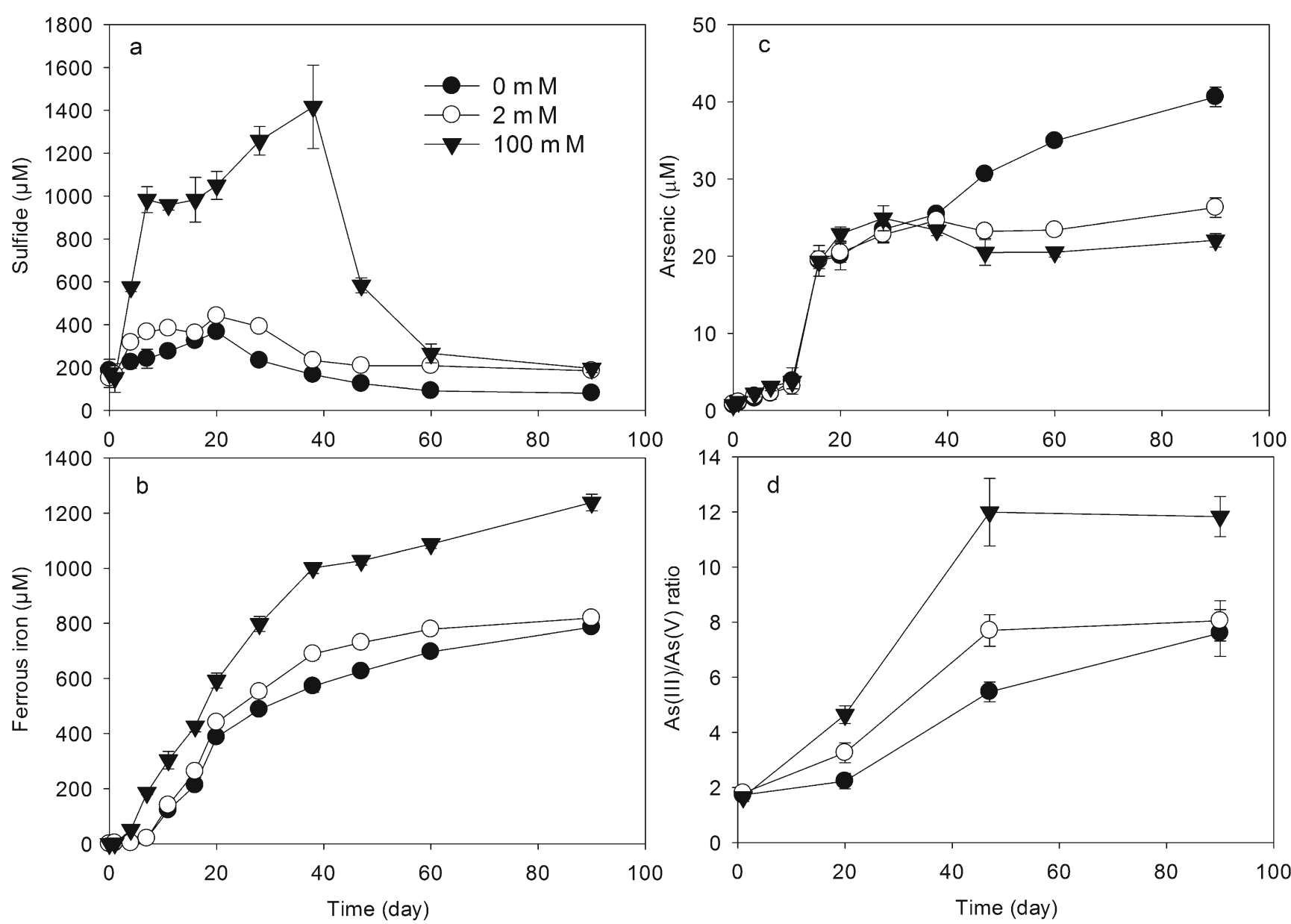

Fig. 1 Concentrations of sulfide (a), ferrous iron (b), and arsenic (c) and the ratio of $\mathrm{As}(\mathrm{III}) / \mathrm{As}(\mathrm{V})(\mathbf{d})$ in the soil solution of the treatments with 0,2 , and $100 \mathrm{mM} \mathrm{SO}_{4}{ }^{2-}$. Bars represent the standard errors $(n=4)$

$\mathrm{SRB}>-\mathrm{S}+\mathrm{SRB}$ ) (Fig. 2b). SRB inoculation significantly increased As release to the soil solution, while it was not significantly different between the treatments with or without addition of $\mathrm{SO}_{4}{ }^{2-}$ (Fig. 2c). The presence of SRB significantly increased As reduction, shown by the increased ratio of $\mathrm{As}(\mathrm{III}) / \mathrm{As}(\mathrm{V})$ and the higher ratio in the treatments with $\mathrm{SO}_{4}{ }^{2-}$ addition (Fig. 2d).

\subsection{Sulfate addition changes As bioavailability and its uptake into rice plants}

Pot experiment was then conducted to investigate the effect of $\mathrm{SO}_{4}{ }^{2-}$ addition on As bioavailability and its uptake into rice plants. After flooding, the redox potential (Eh) decreased greatly in 2 weeks and then to a steady level (Fig. 3). Soil with rice growth had higher Eh than the soil without rice plant, and the sulfate addition decreased the Eh at a later time. Concentrations of $\mathrm{Fe}^{2+}$ and $\mathrm{As}$ in the soil solution increased greatly in the first 30 days and then decreased later (Figs. 4 and 5). The treatments with sulfur application into paddy soil had a higher $\mathrm{Fe}^{2+}$ concentration in soil solution in the first 5 weeks and then lower than treatments with no sulfate addition, by 15.8 and
$18.9 \%$ with or without rice plants, respectively (Fig. 5). Arsenic concentration in soil solution was also increased by the addition of sulfate in the first 4 weeks, and then decreased and lower than the treatments without sulfate addition, by 20.8 and $26.2 \%$ with or without rice plants, respectively (Fig. 4). The presence of rice plants decreased the concentrations of As and $\mathrm{Fe}^{2+}$ in soil solution compared to the controls without rice plants, respectively (Figs. 4 and 5). Arsenic speciation in soil solution was mainly As(III) and also small amounts of As(V) and DMAs(V) (Fig. 6).

Application of sulfate significantly reduced the As concentration in rice roots and iron plaque by 22.6 and $30.5 \%$, while also a numerically not statistical decrease of about $5 \%$ in shoots compared to non-sulfur application treatment (Fig. 7).

\section{Discussion}

Results from the present study demonstrate that microbial reduction of $\mathrm{As}$ and $\mathrm{Fe}$ in anaerobic paddy soil resulted in As release from paddy soil. SRB community also had the ability of $\mathrm{As}(\mathrm{V})$ and $\mathrm{Fe}(\mathrm{III})$ reduction. However, under the activity of 

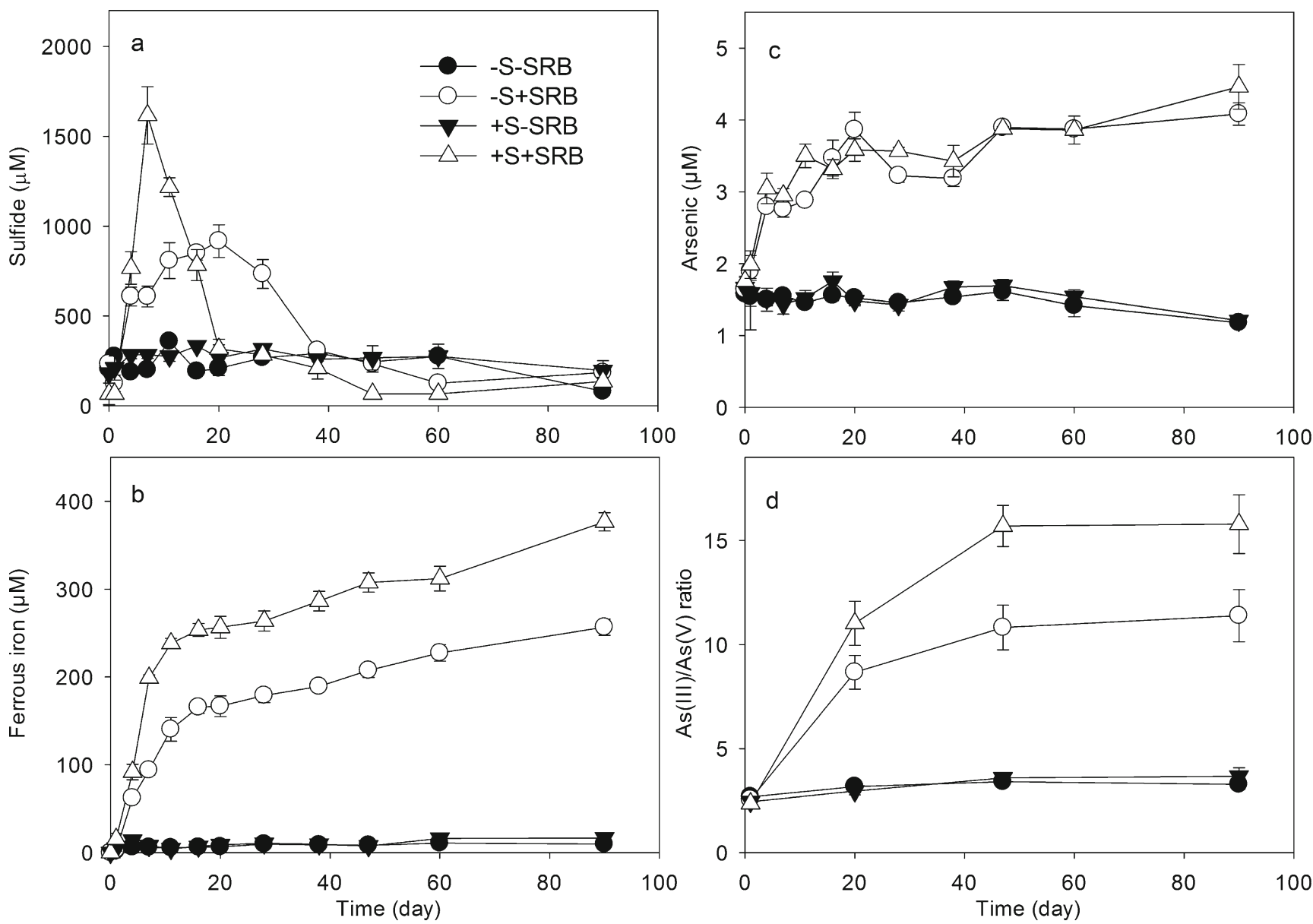

Fig. 2 Concentrations of sulfide (a), ferrous iron (b), and arsenic (c) and the ratio of $\mathrm{As}(\mathrm{III}) / \mathrm{As}(\mathrm{V})(\mathbf{d})$ in the soil solution. $-\mathrm{S}-\mathrm{SRB}$ without $\mathrm{SO}_{4}{ }^{2-}$ and without $\mathrm{SRB}$ addition, $-S+S R B$ without $\mathrm{SO}_{4}{ }^{2-}$ and with $\mathrm{SRB}$

addition, $+S-S R B$ with $\mathrm{SO}_{4}{ }^{2-}$ and without $\mathrm{SRB}$ addition, $+S+S R B$ with $\mathrm{SO}_{4}{ }^{2-}$ and with SRB addition. Bars represent the standard errors $(n=4)$

SRB and sulfate addition, As(III) mobility could later be lower in the soil solution, which limited As bioavailability to rice

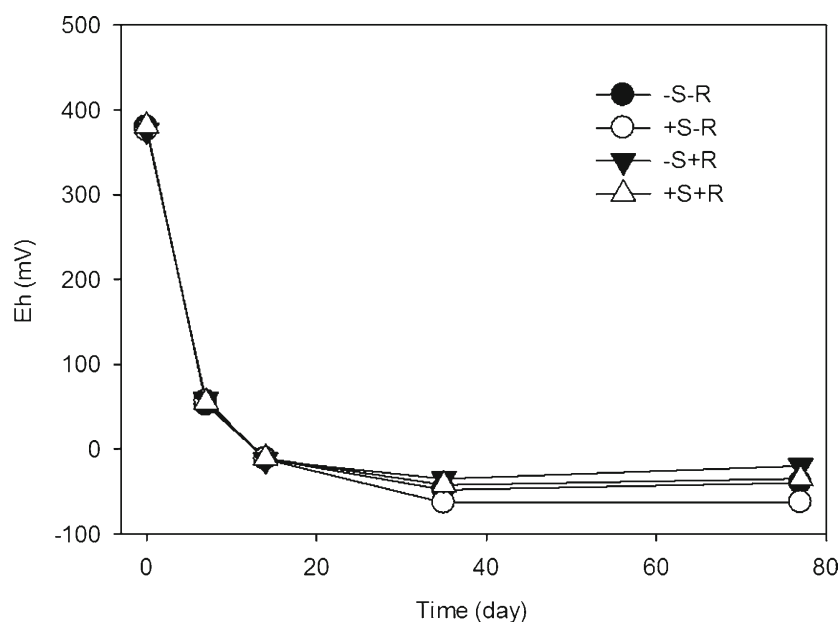

Fig. 3 Redox potential (Eh, vs. $S H E)$ in soil during rice culture in the four treatments. $-S-R$ without sulfur addition and without rice cultivation, $+S$ $R$ with sulfur addition and without rice cultivation, $-S+R$ without sulfur addition and with rice cultivation, $+S+R$ with sulfur addition and with rice cultivation. Bars represent the standard errors $(n=4)$ plants in the anaerobic paddy soil. Sulfate application into the paddy soil thus decreased As uptake into the rice plants and

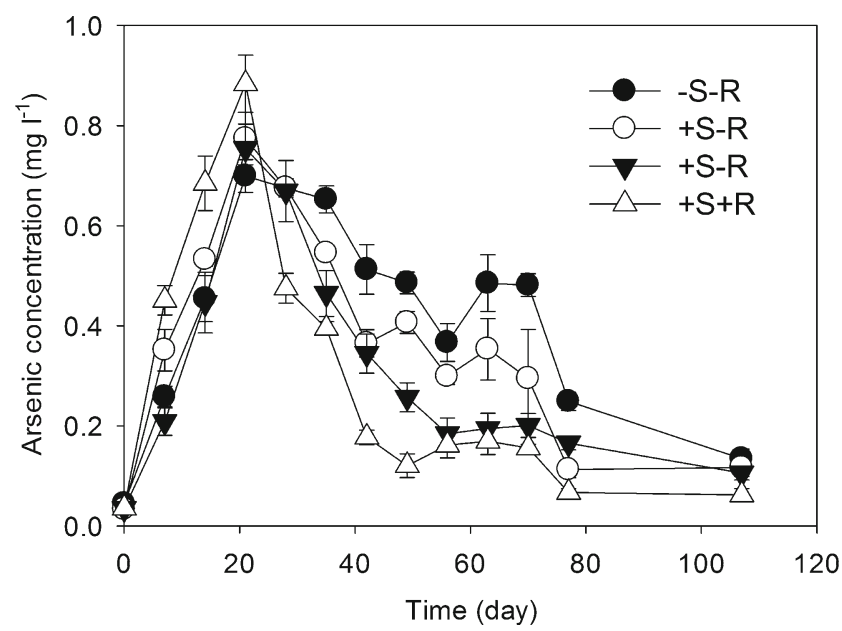

Fig. 4 Arsenic concentrations in soil solution during rice culture in the four treatments. $-S-R$ without sulfur addition and without rice cultivation, $+S-R$ with sulfur addition and without rice cultivation, $-S+R$ without sulfur addition and with rice cultivation, $+S+R$ with sulfur addition and with rice cultivation. Bars represent the standard errors $(n=4)$ 


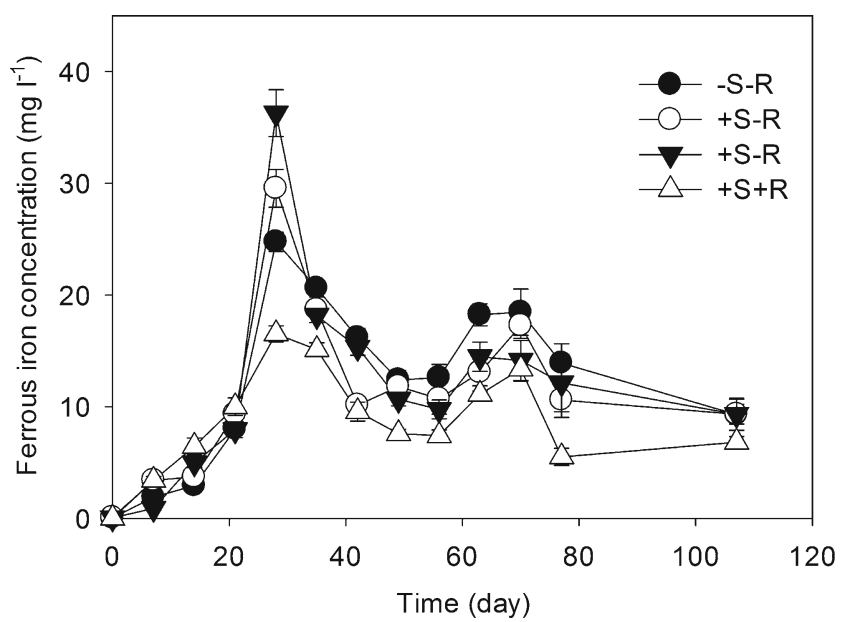

Fig. 5 Concentrations of ferrous iron in soil solution during rice culture in the four treatments. $-S-R$ without sulfur addition and without rice cultivation, $+S-R$ with sulfur addition and without rice cultivation, $-S+$ $R$ without sulfur addition and with rice cultivation, $+S+R$ with sulfur addition and with rice cultivation. Bars represent the standard errors $(n=4)$

can be used in decreasing As uptake in anaerobically cultivated rice.

In anaerobic paddy soil, microbes mediated the reduction of As, Fe, and $\mathrm{S}$, while sterilized paddy soil showed no reduction in the release of these elements (Fig. 2). Most energy for microbes is generated from respiration supported by $\mathrm{O}_{2}$ as the electron acceptor and under anaerobic conditions like flooded paddy soil, also by $\mathrm{Fe}(\mathrm{III}), \mathrm{SO}_{4}{ }^{2-}$, and $\mathrm{As}(\mathrm{V})$ etc., which is conducted by special microbial groups, and their activities determine the speciation and fate of elements in the environment (Newman et al. 1997; Macy et al. 2000; Lovley and

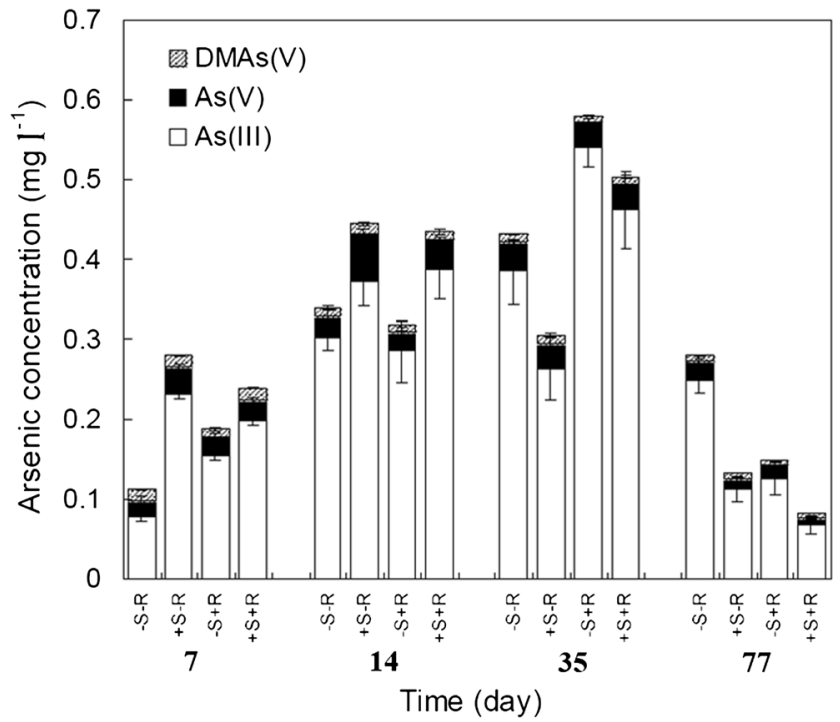

Fig. 6 Arsenic speciation in soil solution during rice culture in the four treatments. $-S-R$ without sulfur addition and without rice cultivation, $+S$ $R$ with sulfur addition and without rice cultivation, $-S+R$ without sulfur addition and with rice cultivation, $+S+R$ with sulfur addition and with rice cultivation. Bars represent the standard errors $(n=4)$

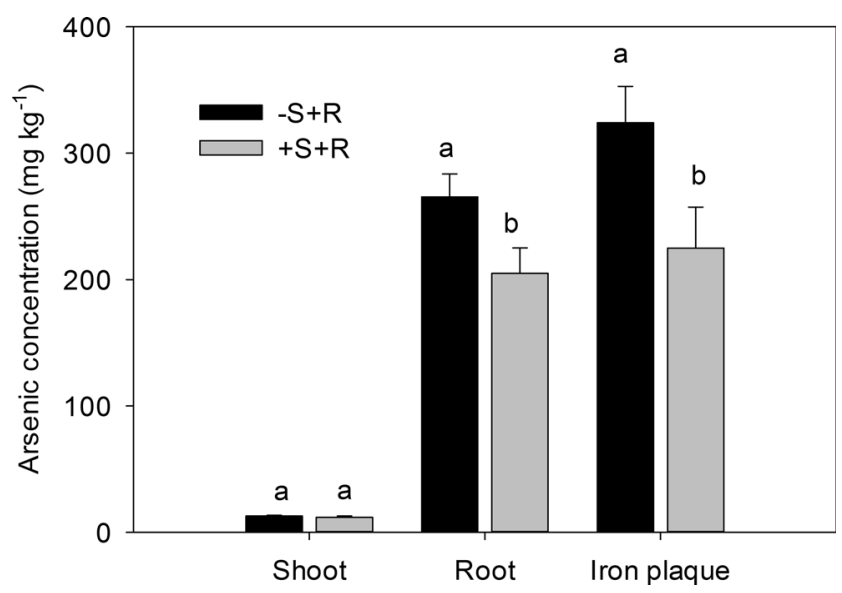

Fig. 7 Arsenic concentrations in the rice shoots, roots, and iron plaque of the two treatments with or without sulfur addition into the paddy soil. Bars represent the standard errors $(n=4)$. Different letters mean significant differences between the two treatments

Coats 2000; Saalfield and Bostick 2009). A stable community of SRB was obtained using enrichment culture method by $\mathrm{SO}_{4}{ }^{2-}$ enrichment for 15 transfers and was also suggested to use the $\mathrm{As}(\mathrm{V})$ and $\mathrm{Fe}(\mathrm{III})$ as the electron acceptor under anaerobic soil conditions (Fig. 2), but the amount of As reduction release by the SRB group was much lower than that in the non-sterilized dry soil incubation (Figs. 1c and 2c); this suggested that the SRB is only a part of the As(V)-reducing bacteria in the paddy soil. It was also previously shown that some of the SRB species have the ability of dissimilatory respiration of As(V) (Newman et al. 1997; Macy et al. 2000), suggesting that dissimilatory $\mathrm{As}(\mathrm{V})$ reduction also occurs in the sulfidogenic zone. Saalfield and Bostick (2009) suggest that bacterial reduction of $\mathrm{As}(\mathrm{V})$ is necessary for As sequestration in sulfides, even where sulfate reduction is active. So, the cooccurrence of As(III), Fe(II), and sulfide thus enables the formation of As sulfide or As-Fe-sulfide minerals. The activity of anaerobic microbes significantly decreased the soil Eh by the production of a large amount of the reductive substance, such as elevated $\mathrm{S}^{2-}, \mathrm{Fe}^{2+}$, and $\mathrm{As}(\mathrm{III})$ (Figs. 1 and 2). The dramatic increase in As concentrations is often seen in systems undergoing dissimilatory $\mathrm{Fe}$ reduction of As-bearing iron oxides (Pedersen et al. 2006).

Though activity of SRB alone may facilitate As reduction for reasons mentioned above, $\mathrm{SO}_{4}{ }^{2-}$ amendment into the paddy soil resulted in decreased As concentration in the soil solution (Figs. 1 and 2). Arsenic concentration in soil solution was lower in the $\mathrm{SO}_{4}{ }^{2-}$ addition treatment, which was also supported by previous findings that active $\mathrm{SO}_{4}{ }^{2-}$ reduction limits aqueous As accumulation in batch experiments (Saalfield and Bostick 2009), and higher $\mathrm{SO}_{4}{ }^{2-}$ resulted in a lower As concentration in flood soil solution (Burton et al. 2014). Sulfur XANES analysis by Saalfield and Bostick (2009) suggested that sulfate-reducing bacteria caused significant changes in $\mathrm{Fe}$ and $\mathrm{S}$ speciation, including reduction of $\mathrm{Fe}$ 
to form magnetite and iron sulfides and formation of solidphase elemental sulfur from aqueous $\mathrm{SO}_{4}{ }^{2-}$. In natural compounds, As bonds primarily to oxygen and sulfur, generating a variety of aqueous species and minerals. Affinity of As to these two elements, along with its stable bonding to methyl groups, constitutes the structural basis for most organic and biosynthetic compounds (O'Day 2006). According to the chemical speciation model in Burton et al. (2014), under our paddy soil conditions, formation of an $\mathrm{As}_{2} \mathrm{~S}_{3}$-like species is likely, and As retention as an $\mathrm{As}_{2} \mathrm{~S}_{3}$-like complex is associated with mackinawite (tetragonal $\mathrm{FeS}$ ) rather than as a discrete $\mathrm{As}_{2} \mathrm{~S}_{3}$ phase in the flooded soils. Microbial sulfate reduction often resulted in subsequent precipitation of As by a mixed population of SRB (Jong and Parry 2003; Rittle et al. 1995). Conversely, under sulfate-reducing conditions, As may react with excess sulfide to first form soluble thioarsenite complexes, which may then precipitate as As-S solid phases such as amorphous $\mathrm{As}_{2} \mathrm{~S}_{3}$ or realgar (AsS) as dissolved sulfide concentrations increase (O'Day et al. 2004; Bostick et al. 2005). The thioarsenite complexes are more easily formed in a low $\mathrm{Fe}^{2+}$ and high organic matter environment (Couture et al. 2013; Burton et al. 2014), while not commonly reported in paddy soil. It is likely that the consistently decreased $\mathrm{S}^{2-}$ concentrations at a later time of incubation experiment 1 , maintained by reaction or precipitation with iron and dissolved As(III) concentrations, were due to limited As reduction as well as its strong adsorption to Fe solids.

Paddy soils are high in microbial reduction activity and create anoxic conditions which are high in $\mathrm{S}^{2-}$ and $\mathrm{Fe}^{2+}$. The reduction of iron and As usually resulted in high As dissolution from the soil minerals, mainly in the form of As(III), and caused high As uptake in rice (Jia et al. 2012). Arsenic speciation was mainly As(III) during rice growth (Fig. 6), and As concentration had a linear relationship with $\mathrm{Fe}^{2+}$ concentration in soil solution, suggesting that the $\mathrm{Fe}$ reduction and $\mathrm{As}(\mathrm{V})$ reduction induced $\mathrm{As}(\mathrm{III})$ release. Arsenic bioavailability and uptake into rice plants decreased under $\mathrm{SO}_{4}{ }^{2-}$ application (Fig. 5), which may be through the coprecipitation of As(III) with reducing $\mathrm{S}^{2-}$ and iron sulfides under anaerobic conditions. It has been suggested that low As mobility in soil solution is related to the conditions of high sulfur in anaerobic paddy soils and also in sediments of aquifers, peat, and floodplains (O'Day et al. 2004; Langner et al. 2012; Burton et al. 2014). The release of As to soil solution and its accumulation in rice plants in the transition from oxidizing to reducing may depend on the amount of available iron and sulfur in the paddy soil, rate of reductive dissolution of $\mathrm{Fe}$ (III) phases, $\mathrm{SO}_{4}{ }^{2-}$ reducing rate, and the rate of $\mathrm{As}$ precipitation with $\mathrm{S}^{2-}$. Previous research also showed a decreased As uptake in rice plants with sulfur addition in the rice growth media (Hu et al. 2007); here, we elucidated the role of sulfate reduction in limited As bioavailability in the paddy soil. This study suggests that As-contaminated paddy soil might be alleviated at low cost by stimulating microbial sulfate reduction and As precipitation in the subsurface through sulfur fertilization.

\section{Conclusions}

The results overall suggested the important role of sulfur and the SRB in As biogeochemical cycling in anaerobic paddy soil, implying a lower As mobility and bioavailability to rice plants under sulfur-enriched paddy soil, and an efficient way to reduce As accumulation in rice plants by sulfur fertilization in paddy soils. Direct evidence for the solid-phase As speciation interaction with $\mathrm{S}$ and $\mathrm{Fe}$ in the anaerobic paddy soil needs to be further investigated, using the X-ray diffraction (XRD), X-ray photoelectron spectroscopy (XPS), X-ray absorption near edge structure (XANES), or some other relevant techniques.

Acknowledgments This work is financially supported by the Natural Science Foundation of China (41401541, 41090280, 41090282).

\section{References}

Bao P, Hu ZY, Wang XJ, Chen J, Ba YX, Hua J, Zhu CY, Zhong M, Wu CY (2012) Dechlorination of p, p'-DDTs coupled with sulfate reduction by novel sulfate-reducing bacterium Clostridium sp. BXM. Environ Pollut 162:303-310

Bostick BC, Fendorf S (2003) Arsenite sorption on troilite (FeS) and pyrite $\left(\mathrm{FeS}_{2}\right)$. Geochim Cosmochim Acta 67:909-921

Bostick B, Fendorf S, Brown G (2005) In situ analysis of thioarsenite complexes in neutral to alkaline arsenic sulphide solutions. Mineral Mag 69:781-795

Burton ED, Jhonston SG, Kraal P, Bush RT, Claff S (2013) Sulfate availability drives divergent evolution of arsenic speciation during microbially mediated reductive transformation of schwertmannite. Environ Sci Technol 47:2221-2229

Burton ED, Jhonston SG, Kocar BD (2014) Arsenic mobility during flooding of contaminated soil: the effect of microbial sulfate reduction. Environ Sci Technol 48:13660-13667

Cord-Ruwisch R (1985) A quick method for the determination of dissolved and precipitated sulfides in cultures of sulfate-reducing bacteria. J Microbiol Methods 4:33-36

Couture RM, Rose J, Kumar N, Mitchell K, Wallschläger D, Cappellen PV (2013) Sorption of arsenite, arsenate, and thioarsenates to iron oxides and iron sulfides: a kinetic and spectroscopic investigation. Environ Sci Technol 47:5652-5659

Fisher JC, Wallschläger D, Planer-Friedrich B, Hollibaugh JT (2008) A new role for sulfur in arsenic cycling. Environ Sci Technol 42:81-85

Gallegos TJ, Han YS, Hayes KF (2007) Spectroscopic investigation of the uptake of arsenite from solution by synthetic mackinawite. Environ Sci Technol 41:7781-7786

Hoeft SE, Kulp TR, Stolz JF, Hollibaugh JT, Oremland RS (2004) Dissimilatory arsenate reduction with sulfide as electron donor: experiments with mono lake water and isolation of strain MLMS-1, a chemoautotrophic arsenate respirer. Appl Environ Microbiol 70: 2741-2747

Hu ZY, Zhu YG, Li M, Zhang LG, Gao ZH, Smith FA (2007) Sulfur (S)induced enhancement of iron plaque formation in the rhizosphere 
reduces arsenic accumulation in rice (Oryza sativa L.) seedlings. Environ Pollut 147:387-393

Huang H, Jia Y, Sun GX, Zhu YG (2012) Arsenic speciation and volatilization from flooded paddy soils amended with different organic matters. Environ Sci Technol 46:2163-2168

Jia Y, Huang H, Sun GX, Zhu YG (2012) Pathways and relative contributions to arsenic volatilization from rice plants and paddy soil. Environ Sci Technol 46:8090-8096

Jia Y, Huang H, Chen Z, Zhu YG (2014) Arsenic uptake by rice is influenced by microbe-mediated arsenic redox changes in the rhizosphere. Environ Sci Technol 48:1001-1007

Jong T, Parry DL (2003) Removal of sulfate and heavy metals by sulfate reducing bacteria in short-term bench scale upflow anaerobic packed bed reactor runs. Water Res 37:3379-3389

Jönsson J, Sherman DM (2008) Sorption of As(III) and As(V) to siderite, green rust (fougerite) and magnetite: implications for arsenic release in anoxic groundwaters. Chem Geol 255:173-181

Kirk MF, Holm TR, Park J, Jin Q, Sanford RA, Fouke BW, Bethke CM (2004) Bacterial sulfate reduction limits natural arsenic contamination in groundwater. Geology 32:953-956

Langner P, Mikutta C, Kretzchmar R (2012) Arsenic sequestration by organic sulphur in peat. Nat Geosci 5:66-73

Li G, Sun GX, Williams PN, Nunes L, Zhu YG (2011) Inorganic arsenic in Chinese food and its cancer risk. Environ Int 37:1219-1225

Liu WJ, Zhu YG, Smith FA, Smith S (2004) Do iron plaque and genotypes affect arsenate uptake and translocation by rice seedlings (Oryza sativa L.) grown in solution culture? J Exp Bot 55:17071713

Lovley DL, Coats JD (2000) Novel forms of anaerobic respiration of environmental relevance. Curr Opin Microbiol 3:252-256

Ma JF, Yamaji N, Mitani N, Xu XY, Su YH, McGrath SP, Zhao FJ (2008) Transporters of arsenite in rice and their role in arsenic accumulation in rice grain. Proc Natl Acad Sci U S A 105:9931-9935

Macy JM, Santini JM, Pauling BV, O’Neill AH, Sly LI (2000) Two new arsenate/sulfate-reducing bacteria: mechanisms of arsenate reduction. Arch Microbiol 173:49-57

Mondal D, Polya DA (2008) Rice is a major exposure route for arsenic in Chakdaha block, Nadia district, West Bengal, India: a probabilistic risk assessment. Appl Geochem 23:2987-2998

Newman DK, Kennedy EK, Coates JD, Ahmann D, Ellis DJ, Lovley DR, Morel FMM (1997) Dissimilatory arsenate and sulfate reduction in Desulfotomaculum auripigmentum sp. nov. Arch Microbiol 168: 380-388

O'Day PA (2006) Chemistry and mineralogy of arsenic. Elements 2:7783

O’Day PA, Vlassopoulos D, Root R, Rivera N (2004) The influence of sulfur and iron on dissolved arsenic concentrations in the shallow subsurface under changing redox conditions. Proc Natl Acad Sci U S A 101:13703-13708
Pedersen HD, Postma D, Jakobsen R (2006) Release of arsenic associated with the reduction and transformation of iron oxides. Geochim Cosmochim Acta 70:4116-4129

Poulton SW, Krom MD, Raiswell R (2004) A revised scheme for the reactivity of iron (oxyhydr) oxide minerals towards dissolved sulfide. Geochim Cosmochim Acta 68:3703-3715

Rahman MM, Ng JC, Naidu R (2009) Chronic exposure of arsenic via drinking water and its adverse health impacts on humans. Environ Geochem Health 31:189-200

Renock D, Gallegos T, Utsunomiy S, Hayes K, Ewing RC, Becker U (2009) Chemical and structural characterization of As immobilization by nanoparticles of mackinawite $\left(\mathrm{FeS}_{\mathrm{m}}\right)$. Chem Geol 68:116125

Rittle KA, Drever JI, Colberg PJS (1995) Precipitation of arsenic during bacterial sulfate reduction. Geomicrobiol J 13:1-11

Roberts LC, Hug SJ, Dittmar J, Voegelin A, Kretzschmar R, Wehrli B, Cirpka OA, Saha GC, Ali MA, Badruzzaman ABM (2010) Arsenic release from paddy soils during monsoon flooding. Nat Geosci 3(1): 53-59

Saalfield SL, Bostick BC (2009) Changes in iron, sulfur, and arsenic speciation associated with bacterial sulfate reduction in ferrihydrite-rich systems. Environ Sci Technol 43:8787-8793

Smith AH, Lingas EO, Rahman M (2000) Contamination of drinkingwater by arsenic in Bangladesh: a public health emergency. Bull World Health Organ 78:1093-1103

Stroud JL, Norton GJ, Islam MR, Dasgupta T, White RP, Price AH, Meharg AA, McGrath SP, Zhao FJ (2011) The dynamics of arsenic in four paddy fields in the Bengal delta. Environ Pollut 159:947-953

$\mathrm{Su}$ YH, McGrath SP, Zhao FJ (2010) Rice is more efficient in arsenite uptake and translocation than wheat and barley. Plant Soil 328:2734

Sun GX, Williams PN, Carey AM, Zhu YG, Deacon C, Raab A, Feldmann J, Islam RM, Meharg AA (2008) Inorganic arsenic in rice bran and its products are an order of magnitude higher than in bulk grain. Environ Sci Technol 42:7542-7546

Taylor GJ, Crowder A (1983) Use of the DCB technique for extraction of hydrous iron oxides from roots of wetland plants. Am J Bot 70: 1254-1257

Wilkin RT, Wallschläger D, Ford RG (2003) Speciation of arsenic in sulfidic waters. Geochem Trans 4:1-7

Xu XY, McGrath SP, Meharg AA, Zhao FJ (2008) Growing rice aerobically markedly decreases arsenic accumulation. Environ Sci Technol 42:5574-5579

Zhu YG, Williams PN, Meharg AA (2008a) Exposure to inorganic arsenic from rice: a global health issue? Environ Pollut 154:169-171

Zhu YG, Sun GX, Lei M, Teng M, Liu YX, Chen NC, Wang LH, Carey AM, Deacon C, Raab A, Meharg AA, Williams PN (2008b) High percentage inorganic arsenic content of mining impacted and nonimpacted Chinese rice. Environ Sci Technol 42:5008-5013 